\title{
DETERMINATION OF CONSUMER PREFERENCES OF DIFFERENT GROUPS OF FOOD
}

\author{
Yana Biletska ${ }^{1}$ \\ ya.belecka@karazin.ua \\ Anna Perepelytsia ${ }^{1}$ \\ irtb@karazin.ua \\ Olha Bilovska \\ o.bilovska@karazin.ua \\ ${ }^{1}$ International E-commerce and Hotel\&Restaurant Business Department \\ V. N. Karazin Kharkiv National University \\ 4 Svobody sq., Kharkiv, Ukraine, 61022
}

\begin{abstract}
Marketing research of consumer preferences of consumers when purchasing various groups of food products are conducted, the factors affecting respondents when purchasing food products are studied. It is established that the consumer in its daily diet takes $10.5 \%$ of bakery products; $7.1 \%$ cereals and soups based on cereals and legumes. $9.5 \%$ of respondents consume confectionery for breakfast and during snacks, and $6.2 \%$ consume sweets. Meat is consumed daily by $5.8 \%$ of respondents. Products based on meat $-10.7 \% .8 .1 \%$ of respondents consume fish daily and fish-based products $3.1 \% .5 .9 \%$ consume milk every day, and milk-based products $-10.2 \%$ of respondents. 12.8 and $10.1 \%$ of the daily diet of respondents are vegetables and fruits (respectively). It is established that the recommended consumption norms are exceeded for such food groups as sweets, meat-based products, and confectionery. Diet within the norm for the consumption of bakery products, milk, fish and fish-based products. Inadequate consumption of cereals, legumes, meat, fruits. Based on the results, it is determined that the consumer prefers food products that have a pleasant (familiar) taste, without harmful, unnatural substances, high nutritional value at a low price. The studies are useful for specialists in food industry who work and developnew foods and diets.
\end{abstract}

Keywords: food products, food diet, marketing, consumer preferences.

DOI: $10.21303 / 2504-5571.2020 .001136$

\section{Introduction}

The nutrition of a modern person determines its state of health, affects the quality and life expectancy. Due to the rational consumption of various food groups, it is possible to significantly reduce the risk of cardiovascular, iodine-deficient diseases, diabetes and cancer, that is, the most dangerous diseases [1]. Dietary diets should include various groups of food products that are carriers of vitamins, minerals, dietary fiber, protein, amino acids and other substances $[2,3]$. The growing "army" of healthy food fans confirms the relevance of this direction [4], but the success of various food groups in the market depends on how much the manufacturer has previously taken into account the needs of the consumer [5].

When conducting a literary analysis, it is established that research on consumer preferences for the purchase of various groups of food products is insufficiently covered in scientific works, the factors affecting respondents when they are purchased are poorly studied, therefore this complex of studies is relevant.

Recently, issues related to the production of competitive goods, which could be implemented in European countries and would meet generally accepted standards, have gained popularity [6]. Creating a high-quality product must begin with marketing research to identify consumer motivation and preferences [7]. Identification of customer needs will lead to the development of a product that, in terms of its consumer properties and economic indicators, will satisfy the consumer [8]. The food market of Ukraine is insufficiently provided with products of various food groups, and products for special dietary consumption are extremely in demand [9].

The aim of research is determination of the consumer preferences of the upper food groups. 


\section{Materials and Methods}

In the course of the study, an expert method of consumer survey is used [10], a questionnaire is developed for the survey, consisting of information blocks aimed at solving the following problems: study of consumer preferences when buying various food groups; study of factors influencing respondents when they purchase.

The studies are carried out in the form of a test survey by means of a questionnaire and by using an Internet resource (filling out a questionnaire in the social network of face book and instagram). The survey involves 600 people. The distribution of respondents is as follows: depending on the gender $-45 \%$ of males, $55 \%$ of females. According to age, the respondents are distributed as follows: $29 \%$ of respondents from 7 to 18 years old, $18 \%$ of respondents from 18 to 25 years old; $31 \%$ of respondents from 25 to 49 years old; $22 \%$ of respondents 50 years or more. Depending on the level of education: with higher education - $50 \%$, incomplete secondary $29 \%$, with secondary $-21 \%$. By occupation, the sample includes teachers $-8 \%$; workers $-9 \%$; employees - $10 \%$; pensioners - $22 \%$; students and schoolchildren - $30 \%$; entrepreneurs $15 \%$. The share of unemployed (unemployed, housewives) is $4 \%$. Another occupation is indicated by $2 \%$ of respondents.

\section{1. Study of consumer preferences regarding choices when purchasing various food groups \\ The study of consumer preferences regarding the choice when buying various groups of} food products is shown in Table 1.

It is found that most consumers in their daily diet consume $10.5 \%$ of bakery products (bread) $7.1 \%$ consume cereals and soups based on cereals; $9.5 \%$ of respondents at breakfast and during snacks consume confectionery, and $6.2 \%$ sweets (cakes, chocolate, sweets). Meat is consumed daily by $5.8 \%$ of respondents, but the consumption of meat-based products is almost doubled and amounts to $10.7 \% .8 .1 \%$ of respondents consume fish daily, and fish-based products $3.1 \%$. $5.9 \%$ consume milk every day, and milk-based products consume $10.2 \%$ of the diet. 12.8 and $10.1 \%$ of the daily diet are vegetables and fruits (respectively).

Table 1

Study of consumer preferences regarding the choice when buying various groups of food products

\begin{tabular}{cccc}
\hline Food groups & \% of actual consumption, $\%$ & Recommended consumption, \% & $\begin{array}{c}\text { \% covering recommended } \\
\text { consumption (CRC), \% }\end{array}$ \\
\hline Bakery products & 10.5 & 12 & 87.5 \\
Cereals, (legumes) & 7.1 & 10 & 71 \\
Confectionery & 9.5 & 3 & 316 \\
Sweets & 6.2 & 1 & 620 \\
Meat & 5.8 & 10 & 58 \\
Meat-based products & 10.7 & 2 & 538 \\
Fish & 8.1 & 10 & 81 \\
Fish based products & 3.1 & 3 & 103 \\
Milk & 5.9 & 5 & 118 \\
Milk based products & 10.2 & 4 & 255 \\
Vegetables & 12.8 & 20 & 64 \\
Fruit & 10.1 & 20 & 51
\end{tabular}

Note: \% of recommended consumption, source [1]

\section{2. The factors affecting respondents when purchasing food products}

During the study, it is necessary to determine consumer properties, to which the potential consumer pays attention in the first place. Fig. 1 shows the factors affecting respondents when purchasing food. 


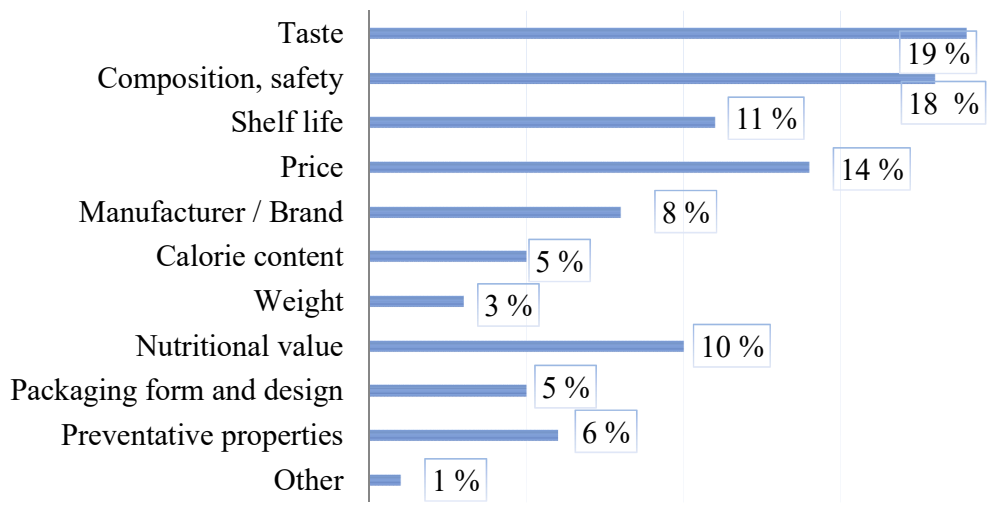

Fig. 1. Factors affecting respondents when purchasing food

It is found that respondents when choosing food products primarily pay attention to the taste of the product $-19 \%$, composition and safety $-18 \%$, price $-14 \%$. Also, a modern consumer is guided by such criteria as nutritional value $(10 \%)$, shelf life $(11 \%)$, the presence of preventive properties of $6 \%$.

\section{Results and Discussion}

Each group of food products is a carrier of substances that affect the functioning of the human body while maintaining its health. Nutritionists believe that for the normal functioning of the human body, it is necessary to consume a variety of food groups, among which vegetables and fruits should be dominant, as carriers of vitamins, minerals, dietary fiber. Meat, fish and legumes, as carriers of protein, amino acids, healthy fats. Bakery products as carriers of carbohydrates - the main source of enenria. Studying consumer preferences when buying various food groups, it is established (Table 1) that the modern consumer in its daily diet significantly exceeds the recommended consumption rates for the most immediate food groups: sweets $(620 \%$ of the covered recommended consumption (CRC) coverage), products based on m meat (various sausages, sausages, \% CRC - 538), confectionery ( $\% \mathrm{CRC}-316)$. Milk-based products (milk pudding, yogurt, fermented baked milk, \% CRC - 255). The daily diets of the respondents are almost within the norm for the consumption of bakery products, milk, fish and fish-based products (\% CRC -87.5 ; 118; 81 and 103, respectively). Inadequate consumption among food groups such as cereals and legumes (\% CRC 71), vegetables (\% CRC 64), meat (\% CRC 58), fruits (\% CRC 51).

Studying the factors that influence respondents when buying food (Fig. 1), it is found that taste dominates - $19 \%$, composition and safety - $18 \%$, price, the lower the better $-14 \%$. The consumer pays attention to nutritional value, shelf life, the presence of preventive (health) properties $-10 ; 11 ; 6 \%$ respectively. For $8 \%$ of respondents, a manufacturer or a trademark that has a certain authority on the rin is important. The shape and design, its weight and calorie content of 5, 3, 5\%, respectively, have almost no effect on the choice when buying food products. It is established that the consumer prefers food products that have a pleasant familiar taste, without harmful, unnatural substances, of increased nutritional value at a low price.

\section{Conclusions}

1. Having analyzed consumer preferences regarding the choice when buying various groups of food products, it is found that $12.8 \%$ of consumers daily try vegetables $12.8 \%$ and fruits $10.1 \%$, which makes them products of mass consumption. During the survey, it is noted that the consumer is interested in the caloric content of the consumed products of its vitamin and mineral composition, and in-depth knowledge of the rules of healthy eating. The next group of products by frequency of consumption is meat-based products $(10.7 \%)$. Raw meat, or $5.8 \%$ buy it as a semi-finished product. The significant difference between related groups can be explained by the readiness of the product for use, which does not require time-consuming preparation of the dish. The consumer prefers cooked, boiled-smoked sausages and meat pastes. $10.5 \%$ of consumers daily try bakery prod- 
ucts, and $9.5 \%$ confectionery products, explaining their choice by the fact that bakery and counter products quickly saturate the body with energy. Milk-based products consume $10.2 \%$ daily, mainly drinking and edible yogurts, kefir, dairy products with a high content of bifidobacteria and lacto bacteria. Only $5.9 \%$ is preferred to native milk, explaining their choice with the lactose content, the content of which [11] in native milk is more than $2 \%$ per $100 \mathrm{ml}$ (compared to fermented milk products $0.2 \%$ ). Lactose is capable of leading to purulent rashes on faces, flatulence, and $60 \%$ of the population aged $55+$ generally has lactose intolerance [12]. $8.1 \%$ of respondents consume fish daily, pay attention to the price, which is quite high for this group of goods, and fish-based products consume only $3.1 \%$. Products such as "Crab sticks", the consumer causes distrust and doubts about the content of fish in them. $7.1 \%$ of respondents consume cereals and soups based on cereals and legumes, and $6.2 \%$ use sweets.

2. Having determined consumer preferences and factors influencing respondents when purchasing food products, it is found that food products with high palatability (19\%) have advantages. The composition has a significant effect on the purchase of various groups of products; it must be natural, without preservatives and sentimental dyes. The modern consumer is guided by such criteria as nutritional value (10\%), shelf life (11\%), the presence of health-improving properties $6 \%$. Prefers products at a low price.

\section{References}

[1] Tsymbalysta, N. V., Davydenko, N. V. (2019). Stan faktychnoho kharchuvannia naselennia ta alimentarne obumovlena zakhvoriuvanist. Problemy kharchuvannia, 1-2, 32-35.

[2] Pavliuk, R. Iu., Cherevko, A. I., Pogarskaia, V. V. et. al. (2002). Novye tekhnologii biologicheski aktivnykh rastitelnykh dobavok i ikh ispolzovanie v produktakh immuno-moduliruiuschego i radiozaschitnogo deistviia. Kharkiv; Kyiv, 205.

[3] Pro skhvalennia proektu Kontseptsii Derzhavnoi naukovo-tekhnichnoi prohramy «Biofortyfikatsiia ta funktsionalni produkty na osnovi roslynnoi syrovyny na 2012-2016 roky» (2011). Postanova NAN Ukrainy No. 189. 08.06.2011. Available at: https:// zakononline.com.ua/documents/show/99126___ 99126

[4] Mardar, M. R., Zhyhunov, D. O., Ustenko, I. A. (2015). Designing of a new cereal product in accordance with consumer preferences. Technology Audit and Production Reserves, 2 (6 (22)), 67-72. doi: http://doi.org/10.15587/2312-8372.2015.41755

[5] Mardar, M. R. (2013). Application of the method of quality functional deployment when developing a new extruded product. Meridian ingineresc, 2, 30-33.

[6] Pro skhvalennia Kontseptsii Zahalnoderzhavnoi prohramy «Zdorovia 2020: ukrainskyi vymir» (2019). Rozporiadzhennia Kabinetu Ministriv Ukrainy No. 1164-r. 31.10.2019. Available at: http://zakon4. rada.gov.ua/laws/show/1164-2011-p

[7] Mardar, M. R., Kordzaya, N. R. (2013). Medical and biological estimation of bread made from a whole wheat grain with inclusion of root crops. Eastern-European Journal of Enterprise Technologies, 4 (10 (64)), 34-39. Available at: http://journals.uran. ua/eejet/article/view/16311

[8] Do Carmo Barbosa Mendes de Vasconce, M., Bennett, R. N., Rosa, E. A. S., Ferreira-Cardoso, J. V. (2009). Industrial processing effects on chestnut fruits (Castanea sativaMill.). 2. Crude protein, free amino acids and phenolic phytochemicals. International Journal of Food Science \& Technology, 44 (12), 2613-2619. doi: http://doi.org/10.1111/j.1365-2621.2009.02092.x

[9] Biletska, Y., Plotnikova, R., Danko, N., Bakirov, M., Chuiko, M., Perepelytsia, A. (2019). Substantiation of the expediency to use iodine-enriched soya flour in the production of bread for special dietary consumption. Eastern-European Journal of Enterprise Technologies, 5 (11 (101)), 48-55. doi: http://doi.org/10.15587/1729-4061.2019.179809

[10] Matison, V. A., Demidova, N. A. (2012). Primenenie metoda razvertyvaniia funkcii kachestva dlia konstruirovaniia produkta $\mathrm{v}$ pischevoi promyshlennosti. Pischevaia promyshlennost, 4, 44-45.

[11] Fang, R., Santiago, N. A., Olds, L. C., Sibley, E. (2000). The homeodomain protein Cdx2 regulates lactase gene promoter activity during enterocyte differentiation. Gastroenterology, 118 (1), 115-127. doi: http://doi.org/10.1016/s0016-5085(00)70420-3

[12] Pereira, P. C. (2014). Milk nutritional composition and its role in human health. Nutrition, 30 (6), 619-627. doi: http:// doi.org/10.1016/j.nut.2013.10.011 